\title{
SISTEM INFORMASI PENGELOLAAN REKAM MEDIS RUMAH SAKIT MENGGUNAKAN JAVA
}

\author{
Muzzammil Haitami ${ }^{1}$, Intan Mutia ${ }^{2}$, Ni Wayan Parwati Septiani ${ }^{3}$ \\ Program Studi Informatika, Universitas Indraprasta PGRI \\ muzzammilhaitami2@gmail.com ${ }^{1}$, as_syifaraa@yahoo.com ${ }^{2}$, niwayan.und@gmail.com³
}

Submitted September 25, 2019; Revised June 22, 2020; Accepted July 2, 2020

\begin{abstract}
Abstrak
Di zaman ini, perkembangan teknologi informasi berperan penting dalam berbagai sektor kehidupan manusia. Khususnya bisnis dibidang rekam medis pasien di rumah sakit. Dampak dari perkembangan teknologi informasi sangat luas sekali, ini bisa dirasakan dalam berbagai aspek kehidupan, salah satu aspek ini bisa di rasakan dalam berbagai aspek yang terkena imbas dari kemajuan teknologi adalah bidang kesehatan. Bidang yang merupakan salah satu faktor penunjang kehidupan manusia, dan bisa dikatakan bahwa kesehatan merupakan faktor terpenting dalam kehidupan manusia. Perancangan sistem informasi ini bertujuan untuk membuat sistem informasi pengolahaan data rekam medis pasien dalam memberikan data yang akurat bagi administrasi dan apotek. Pengelolaan rekam medis pada rumah sakit dirancang menggunakan sistem informasi yang terintegritas dan terkomputerisasi dengan database rumah sakit. Dalam membangun sistem ini digunakan alat bantu perancangan sistem yaitu Diagram Alir Data (DAD), konteks, Nol dan Rinci serta dengan menggunakan bahasa pemrograman Java dengan NetBeans dan database MySQL menggunakan XAMPP.
\end{abstract}

Kata Kunci : Perancangan, Sistem Informasi, Rekam Medis Pasien.

\begin{abstract}
In this era, the development of information technology plays an important role in various sectors of human life. Especially the business in the field of medical records of patients in hospitals. The impact of the development of information technology is very broad, this can be felt in various aspects of life, one of these aspects can be felt in various aspects that are affected by technological advances in the health sector. Field which is one of the supporting factors of human life, and can be said that health is the most important factor in human life. The design of this information system aims to create information systems for processing medical records of patients in providing accurate data for administration and pharmacies. Management of medical records in hospitals is designed using an integrated and computerized information system with hospital databases. in building this system used system design tools that are Data Flow Diagrams (DAD), context, Zero and Detailed and by using the Java programming language with NetBeans and MySQL databases using XAMPP.
\end{abstract}

Keywords : Design, Information Systems, Patient Medical Records.

\section{PENDAHULUAN}

Keberadaan komputer di tengah-tengah kehidupan manusia sekarang ini sudah menjadi komoditas utama. Karena komputer dirasakan dapat menunjang kelancaran pekerjaan yang menuntut kecepatan, keterampilan, keakuratan, dan keefisienan waktu dan tenaga. Komputer membuat segala pekerjaan yang dilakukan oleh manusia dapat dikerjakan secara komputerisasi. Sistem informasi rekam medis merupakan salah satu unsur penting dalam suatu siklus informasi dalam suatu instansi terutama di instansi kesehatan yang berlangsung berinteraksi dengan konsumen, bisa dikatakan bahwa sistem informasi rekam medis adalah "gerbang" untuk memasuki suatu instansi.

Di zaman ini, perkembangan teknologi informasi berperan penting dalam berbagai sektor kehidupan manusia, dan bisnis. Khususnya bisnis dibidang penjualan dan pembelian obat yaitu Apotek. Apotek merupakan suatu tempat atau terminal 
distribusi obat perbekalan farmasi yang dikelola oleh apoteker sesuai standar dan etika kefarmasian.

Rumah Sakit Sentra Medika Depok adalah sebuah instansi yang bergerak di bidang kesehatan pasien. Kegiatan usahanya antara lain memberikan pelayanan yang cepat dan mendiagnosis dengan tepat. Sebagai sebuah instansi kesehatan sangat dibutuhkan sekali kerja sama antara bagian rekam medis Rumah Sakit Sentra Medika Depok sebagai pencatatan diagnosis pasien dengan cepat dan mudah serta dapat di simpan sebagai sejarah pasien atau perjalanan penyakit pasien.

Berdasarkan latar belakang yang telah dipaparkan inilah penulis menerapkan implementasi sistem yang berjudul "Perancangan Sistem Informasi Rekam Medis Pasien Rumah Sakit Sentra Medika Depok Menggunakan Java".

\section{Definisi Perancangan}

Perancangan yang sesungguhnya merupakan suatu aktivitas rekayasa perangkat lunak yang dimaksud untuk membuat keputusan-keputusan utama yang sering kali bersifat struktural" [1].

\section{Definisi Sistem}

Secara sederhana sistem dapat diartikan sebagai suatu kumpulan atau himpunan dari unsur, komponen, atau variabel yang terorganisasi, saling berinterkasi, saling tergantung satu sama lain dan terpadu [2].

\section{Definisi Informasi}

Informasi adalah sekumpulan fakta (data) yang diorganisasikan dengan cara tertentu sehingga mereka mempunyai arti khusus bagi si penerima, dan informasi yang diterima oleh penerima harus sesuai dengan kenyataannya [3].

\section{Definisi Sistem Informasi}

Sistem informasi adalah kumpulan perangkat keras dan perangkat lunak yang dirancang untuk mentrasformasikan data kedalam bentuk informasi [4].

\section{Definisi Rekam Medis}

Rekam Medis adalah berkas yang berisikan catatan dan dokumen tentang identitas pasien, pemeriksaan, pengobatan, tindakan dan pelayanan lain yangtelah diberikan kepada pasien Rekam Medis merupakan milik rumah sakit yang harus dipelihara karena bermanfaat bagi pasien, dokter, maupun bagi rumah sakit. Dokumen rekam medis sangat penting dalam mengemban mutu pelayanan medik yang diberikan oleh rumah sakit dan staf mediknya serta sebagai alat bukti yang akurat di pengadilan [5].

\section{Definisi Pasien}

Pasien adalah orang yang mempunyai kelemahan fisik atau mentalnya menyerahkan pengawasan dan perawatannya, menerima dan mengikuti penerapan pengobatan yang ditetapkan oleh tenaga ksehatan pengobatan yang diteapkan oleh tenaga kesehatan atau para medis yang[6].

\section{Definisi Java}

Java adalah bahasa pemrograman objek murni karena semua kode programnya dibungkus dalam kelas [7].

\section{METODE PENELITIAN}

Penelitian dilakukan di Jl. Raya Bogor Km.33 Cisalak, Kec.Sukmajaya Kota Depok Jawa Barat 16416 Tel.(021)8743790 | Fax.(021)8743230 | IGD.(021)87741669Emailmarketing@sent ramedika-

cisalak.co.idWebhttp://www.sentramedika hospitals.com/cisalak/career.php

Metode penelitian yang digunakan oleh penulis dalam tugas akhir ini adalah metode pengembangan (research and development ( $\mathrm{R} \& \mathrm{D}) /$ forward engineering research) yang menggunakan pendekatan terstruktur.

Metode penelitian R \& D adalah metode penelitian yang digunakan untuk 
menghasilkan produk tertentu, dan menguji keefektifan produk tersebut. Produk tersebut tidak selalu berbentuk benda atau perangkat keras (hardware), seperti buku, alat tulis, dan alat pembelajaran lainnya. Akan tetapi dapat pula dalam bentuk perangkat lunak ( software)[8]. Forward engineering research yang dilakukan mulai dari identifikasi masalah, pengumpulan data, penyusunan model, pengujian model, pengembangan, evaluasi, dan validasi.

\section{Metode Pengumpulan Data}

Metode pengumpulan data yang dilakukan oleh penulis untuk mendapatkan data-data serta informasi untuk mendukung penyempurnaan hasil dari penelitian ini antara lain:

1. Metode Kepustakaan yang penulis lakukan ini dengan mempelajari bukubuku perpustakan, mencari informasi melalui internet serta proses penulis mempelajari dan menyimak erat kaitannya dengan permasalahan yang akan dibahas.

2. Dalam studi lapangan ini dipergunakan teknik pengumpulan data antara lain dengan cara:

a. Wawancara (interview)

Penulis melakukan wawancara kepada Dokter Spesialis Penyakit Dalam yang bernama dr.Prasna Pramita, sp.PD,M.A.R.S.,FINASIM tentang kegiatan yang di lakukan di Rumah Sakit Sentra Medika Depok, khusus nya pada kegiatan rekam medis pasien. Adapun pertanyaan yang penulis tanyakan adalah sebagai berikut:

1) Apakah di Rumah Sakit Sentra Medika laporan dan pencatatan tentang Rekam Medis Pasien masih di tulis di buku besar?

2) Apakah di Rumah Sakit Sentra Medika laporan dan pencatatan tentang Rekam Medis Pasien sering hilang atau rusak dan tidak memiliki salinan nya?
3) Apakah di Rumah Sakit Sentra Medika membutuhkan Sistem Informasi Rekam Medis Pasien?

b. Observasi/pengamatan langsung

Pengertian observasi adalah metode atau cara-cara yang menganalisis dan mengadakan pencatatan secara sistematis mengenai tingkah laku dengan melihat ataupun mengamati individual atau kelompok secara langsung. Observasi dilakukan secara langsung oleh penulis mengenai proses yang digunakan oleh Rumah Sakit Sentra Medika.

c. Dokumentasi

Penulis melakukan pengumpulan data dengan cara melihat dan mencatat data yang ada di Rumah Sakit Sentra Medika Depok.

d. Langkah Pengembangan Sistem

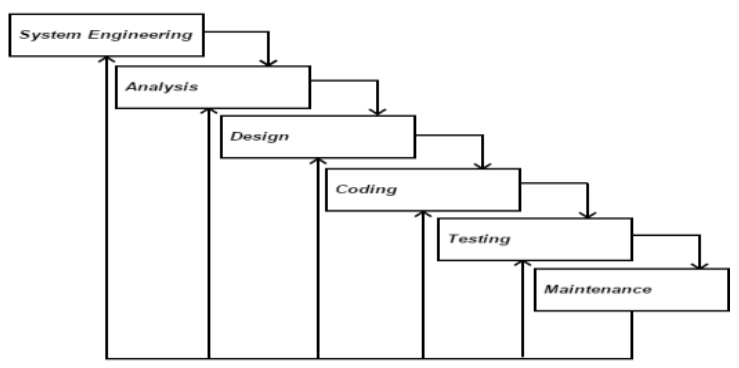

Gambar 1. Model Waterfall

Sumber : Pressman, Roger S. 2012.

\section{HASIL DAN PEMBAHASAN}

Aturan sistem rekam medis pasien pada Rumah Sakit Sentra Medika sebagai berikut :

1. Pendataan Pasien

Proses data pasien yaitu mendapat data pasien dari pasien yang akan melakukan pemeriksaan.Pendataan Pembelian.

2. Proses data pemeriksaan

Dokter menginput data rekam medis pasien yang melakukan pemeriksaan, jika pasien mendapat diagnosa berat maka pasien akan ditindak untuk melakukan rawat inap, dan jika pasien terdiagnosa ringan maka pasien akan di 
sarankan untuk melakukan rawat jalan.

3. Proses rawat inap

Pasien yang melakukan rawat jalan akan diberikan kode ruang, nama ruang, kode perawat dan nama perawat.

4. Proses rawat jalan

Pasien yang melakukan rawat jalan akan mendapat kode resep dan nama resep sesuai dengan hasil diagnose pasien tersebut.

Data Flow Diagram atau dalam bahasa Indonesia menjadi Diagram Alir Data (DAD) adalah refresentasi grafik yang menggambarkan aliran informasi dan transformasi informasi yang diaplikasikan sebagai data yang mengatur dari masukan (input) dan keluaran (output)[9].

Diagram konteks yang diusulkan pada dapat digambarkan sebagai berikut:

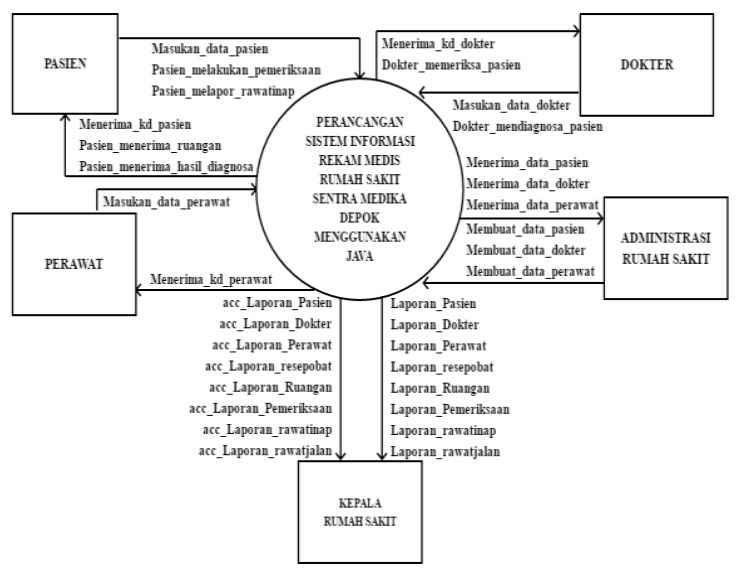

\section{Gambar 2. Diagram Konteks Sistem} yang Diusulkan

Normalisasi merupakan proses pengelompokkan elemen data menjadi tabel-tabel yang menunjukkan entitas dan relasinya[10]. Normalisasi yang penulis masukan hanya yang relasi tabelnya saja, seperti dibawah ini:

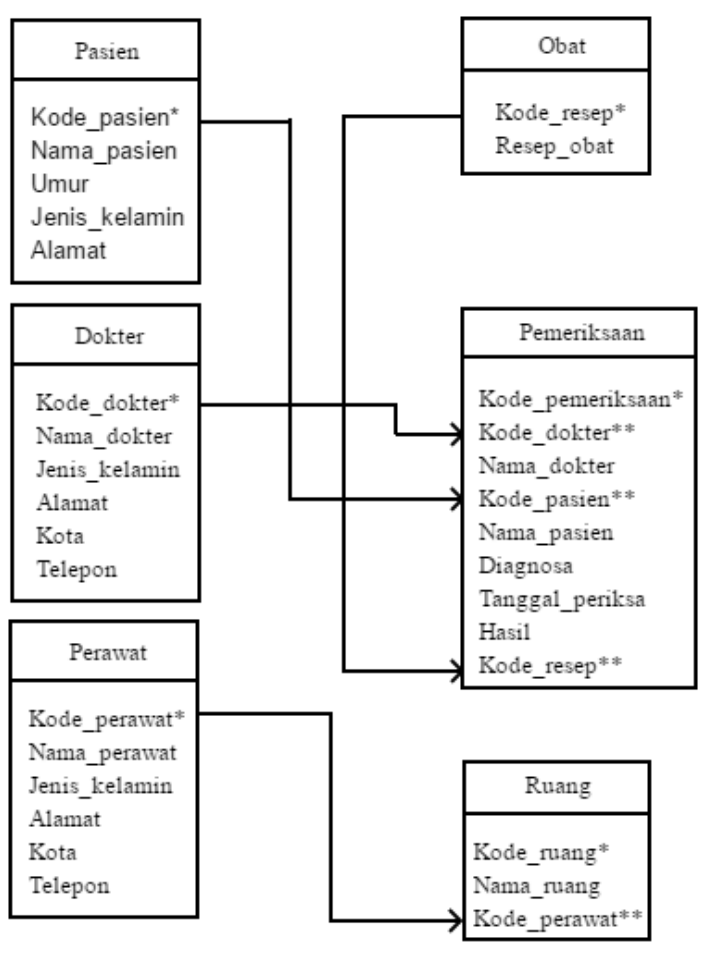

Gambar 3. Relasi Tabel

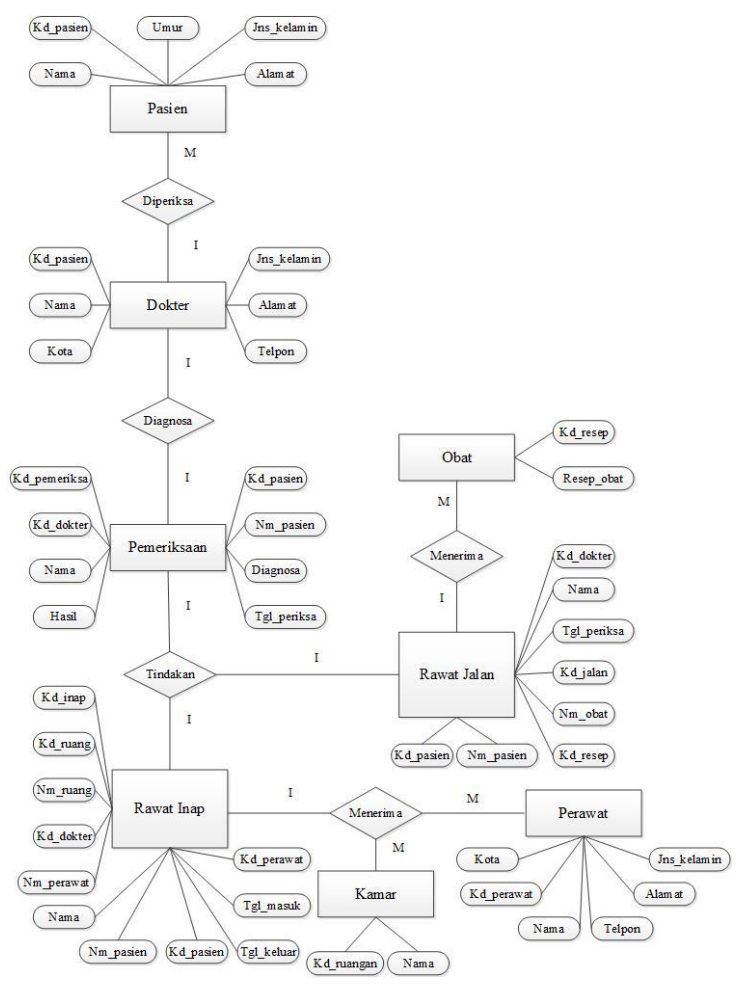

Gambar 4. ERD

(Entity Relationship Diagram ) 
Selanjutnya penulis membuat aplikasi dengan menggunakan java berbasis dekstop dan database mysql. Berikut ini adalah tampilan dari Sistem Informasi Perancangan Rekam Medis Pasien Pasien Sentra Medika Depok:

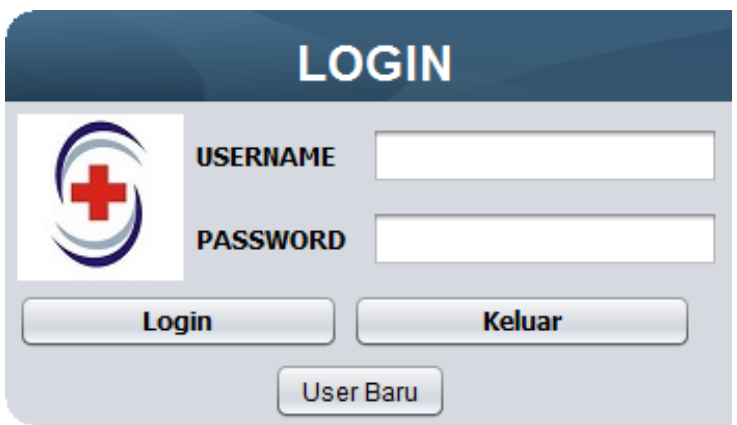

Gambar 5. Tampilan Login

Tampilan login ini terdapat pada awal program. Menu login digunakan sebagai kata kunci sebelum kita memasuki program utama.

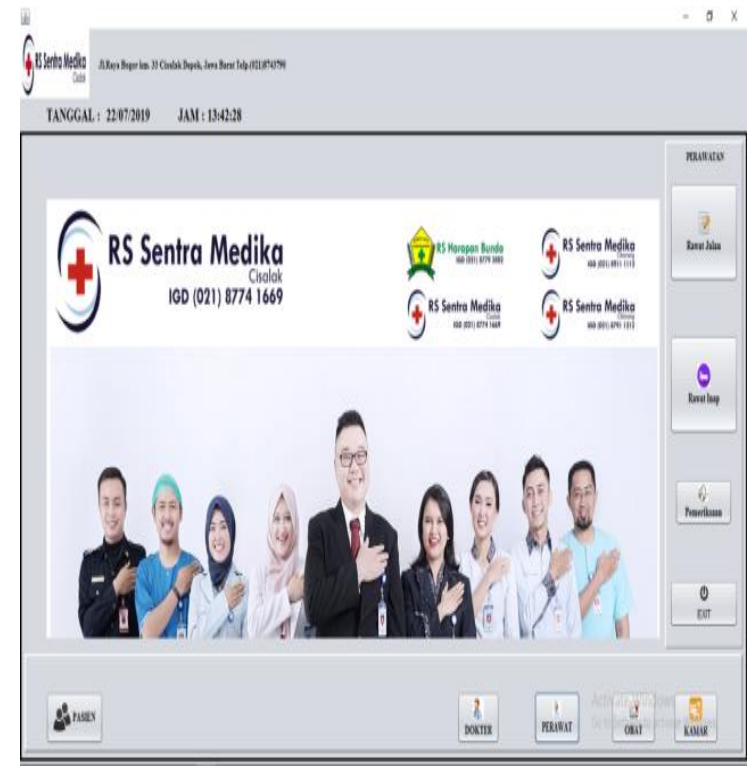

Gambar 6. Tampilan Menu Utama

Merupakan tampilan menu utama yang terdiri dari form-form masukan data untuk pasien, dokter, perawat, resep obat, ruang kamar, pemeriksaan diagnosa pasien, rawat inap, rawat jalan dan form exit untuk keluar dari program.

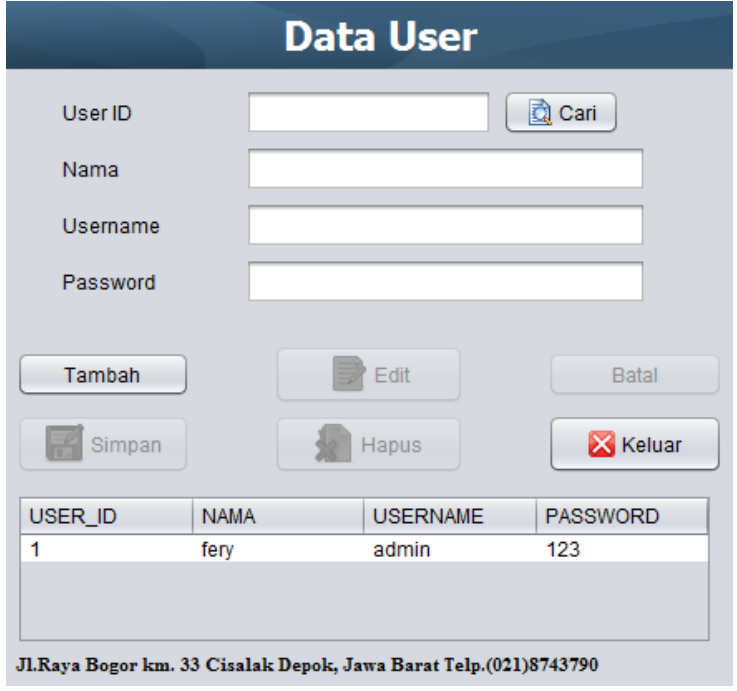

Gambar 7. Tampilan Data User

Tampilan data user adalah tempat pendaftaran bagi pengguna sistem yang baru atau belum pernah menggunakan sistem tersebut.

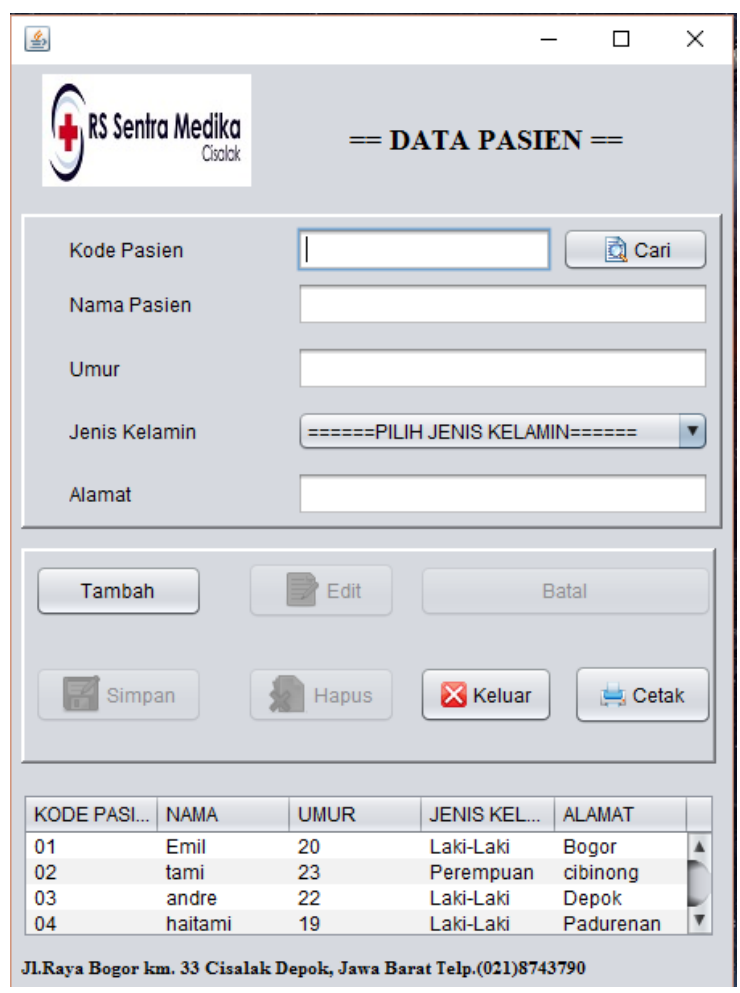

Gambar 8. Tampilan Menu Data Pasien

Merupakan tampilan menu data pasien yang mendaftar untuk melakukan pemeriksaan, pasien yang mendaftar harus memasukan nama pasien, umur, jenis kelamin dan alamat. Setelah melakukan 
pendaftaran, pasien akan mendapatkan kode untuk melakukan pemeriksaan.

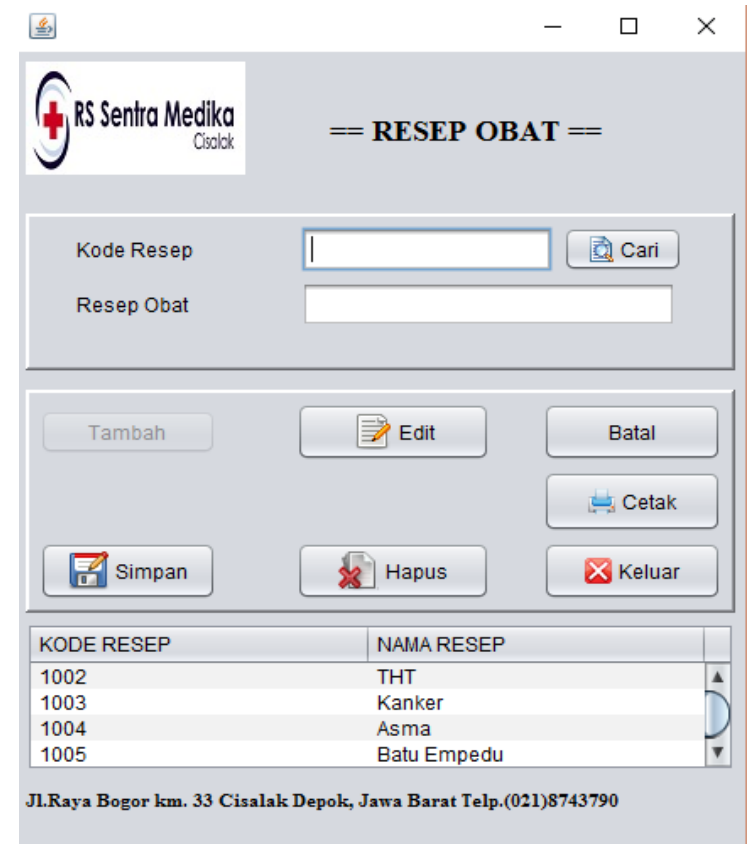

Gambar 9. Tampilan Menu Resep Obat

Merupakan tampilan untuk mengetahui dan memasukan resep obat ataupun menambah resep obat baru untuk penyakit pasien.

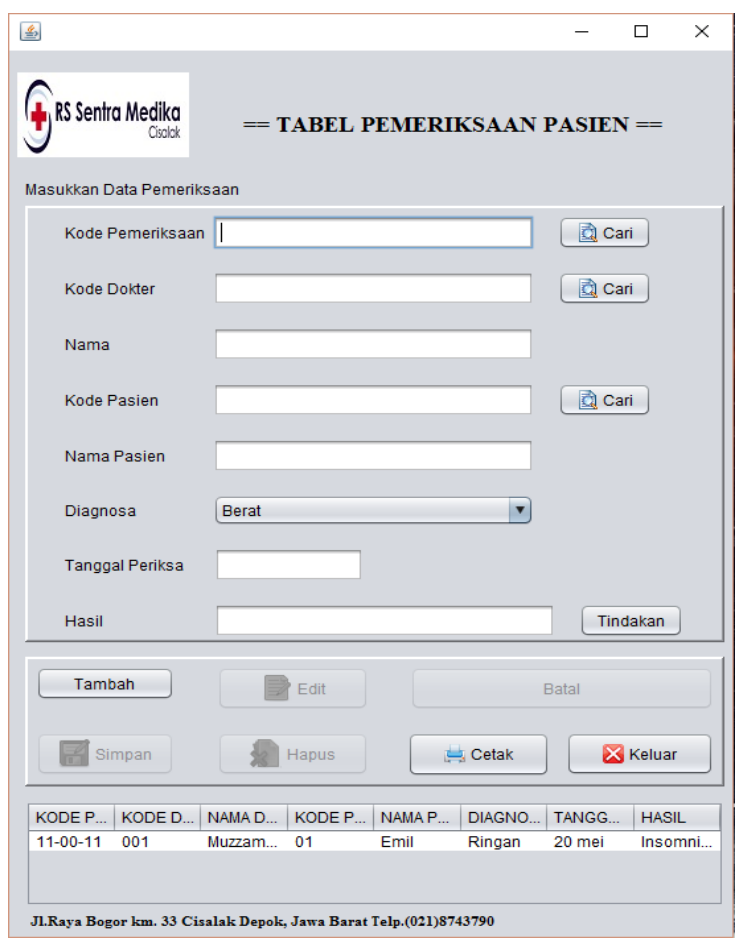

Gambar 10. Tampilan Data Pemeriksaan Pasien
Merupakan tampilan untuk pemeriksaan diagnosa penyakit pada pasien, dan untuk menindak lanjuti penyakit pasien, form pemeriksaan akan menentukan kemana pasien akan ditindak, jika diagnosa pasien berat maka pasien akan di rawat secara intensif dengan melakukan tindakan rawat inap di Rumah Sakit Sentra Medika Depok, tetapi jika diagnosa pasien ringan maka pasien dianjurkan untuk menjalankan rawat jalan di Rumah Sakit Sentra Medika Depok dan pasien akan mendapatkan resep obat yang sesuai dengan penyakit yang di derita oleh pasien.

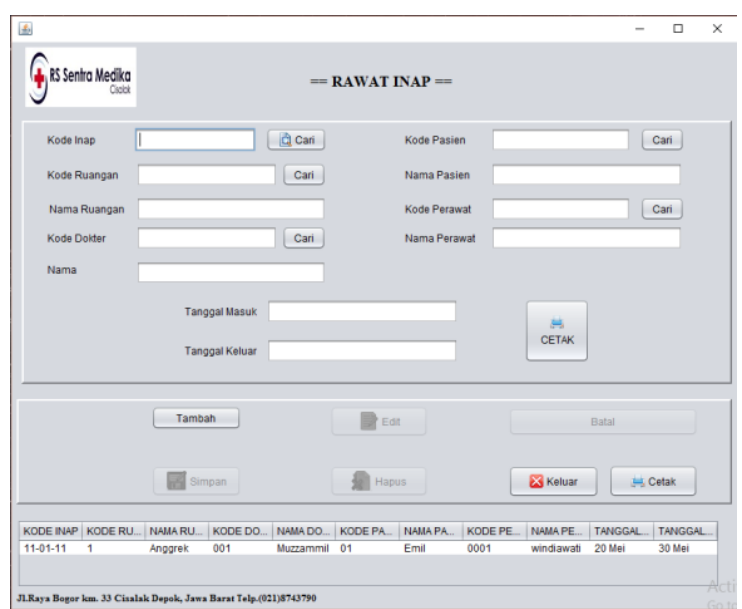

Gambar 11. Tampilan Menu Rawat Inap

Tampilan layar rawat inap untuk memasukan data pasien yang mendapati diagnosa berat, dan menjalani perawatan di rumah sakit dengan mendapat ruang kamar rawat inap, perawat, untuk pasien.

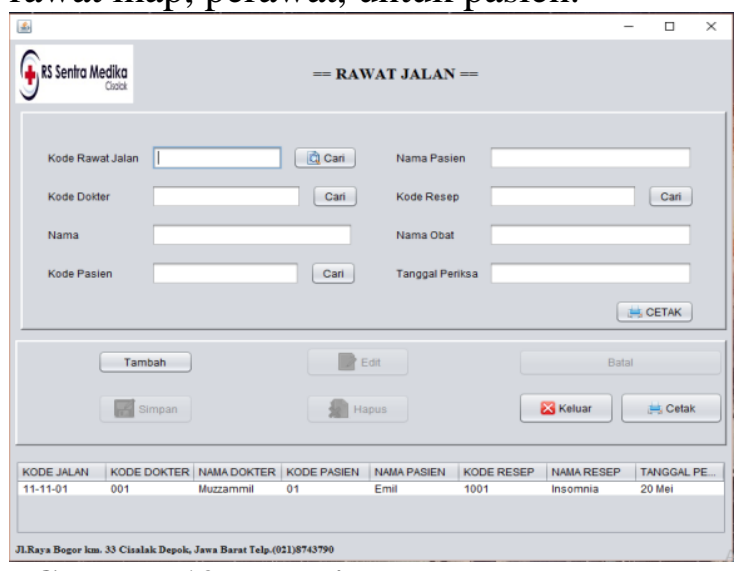

Gambar 12. Tampilan Menu Rawat Jalan

Tampilan layar data untuk pasien yang mendapat diagnosa ringan, maka pasien 
tersebut akan dianjurkan untuk menjalani rawat jalan dan menerima resep obat sesuai dengan penyakit pasien.

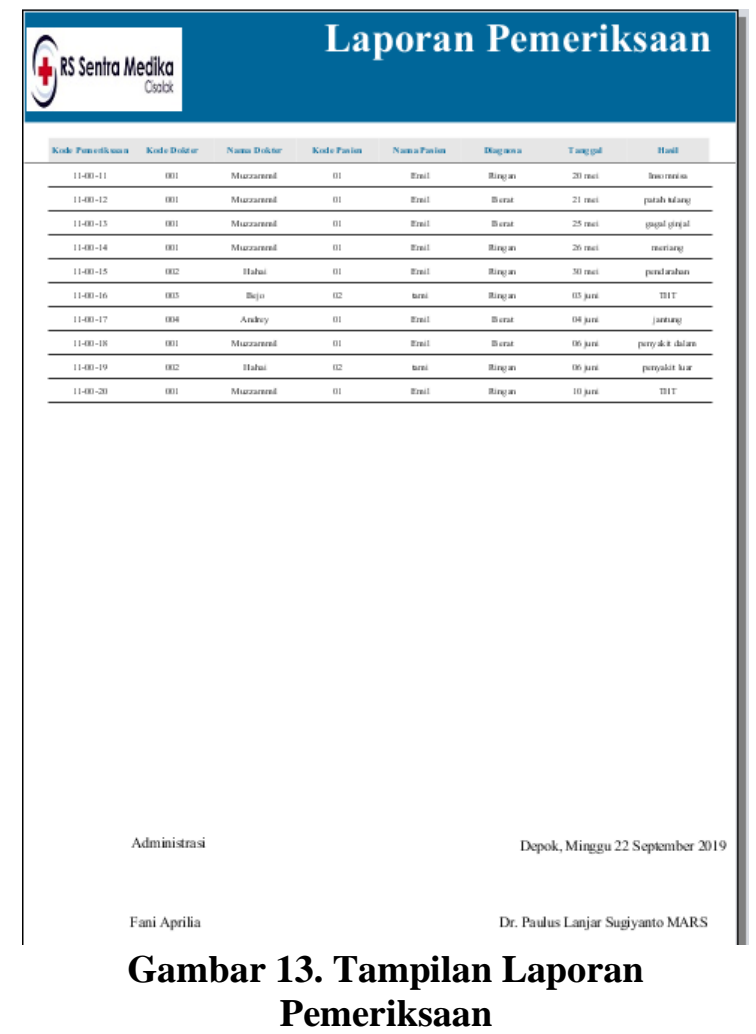

\section{SIMPULAN}

Dengan dibuatnya sistem informasi rekam medis pasien menggantikan sistem lama, kinerja administrasi saat ini menjadi lebih baik dan efektif. Administrasi tidak perlu melakukan penginputan secara manual lagi, karena sistem informasi pengelolaan ini menyediakan form penginputan. Selain itu, sistem informasi pengelolaan ini juga sangat membantu administrasi dalam membuat laporan, karena sistem informasi pengelolaan ini dapat menghasilkan laporan yang dapat langsung dicetak. Perancangan sistem informasi ini bertujuan untuk membuat Sistem Informasi pengolahaan data rekam medis pasien dalam memberikan data yang akurat bagi administrasi dan apotek. Pengelolaan rekam medis pada Rumah Sakit Sentra
Medika Depok dirancang menggunakan sistem informasi yang terintegritas dan terkomputerisasi dengan database Rumah Sakit.

\section{DAFTAR PUSTAKA}

[1] R. S. Pressman, Rekayasa Perangkat Lunak: Pendekatan Praktisi, Software Engineering A Practitioner's Approach 7th Ed Roger S. Pressman. Cambridge: Cambridge University Press, 2010.

[2] T. Sutabri, Analisis Sistem Informasi, Analisa Sistem Informasi. Yogyakarta: Andi, 2012.

[3] M. Yusro, Pengantar Tekhnologi Informasi', System. 2010.

[4] A. Kadir, Pengenalan Sistem Informasi Edisi Revisi, Revisi. Yogyakarta: Andi, 2014.

[5] permenkes, "Permenkes No.269/Menkes/Per/III/2008 tentang Rekam Medis." [Online]. Available:

http://dinkes.surabaya.go.id/portal/fi les/permenkes/dok_dinkes_87.pdf.

[Accessed: 15-Sep-2019].

[6] Prabowo, Hak-hak dan kewajiban setiap pasien. Wilham, 2011.

[7] A. Nogroho, Rekayasa Perangkat Lunak Menggunakan UML \& Java, Rekayasa Perangkat Lunak Menggunakan UML \& Java. Bandung: Informatika, 2014.

[8] Sugiyono, Metode Penelitian Kuantitatif, Kualitatif, dan $R \& D$. Bandung: Alfabeta, 2009.

[9] R. A. Sukamto, Rekayasa Perangkat Lunak Terstruktur Dan Berorientasi Objek. Bandung: Informatika Bandung, 2014.

[10] T. Sutabri, Tata Analisis Sistem Informasi, Analisa Sistem Informasi. Yogyakarta: Andi, 2012. 